\title{
ウェーブレット変換による多自由度構造物の損傷検出*
}

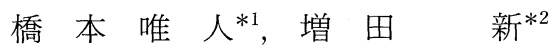 \\ 曽 根彰*2, 射 場 大 輔*2
}

\section{Wavelet-Based Damage Detection of Multi-Degree-of-Freedom Structures}

\author{
Yuito HASHIMOTO*3, Arata MASUDA, \\ Akira SONE and Daisuke IBA \\ ${ }^{* 3}$ Mechanical and System Engineering, Kyoto Institute of Technology,
Goshokaido, Matsugasaki, Sakyo-ku, Kyoto-shi, Kyoto, 606-8585 Japan
}

\begin{abstract}
In this paper, a method is proposed to identify the time and the location of the damage from responses of multi-degree-of-freedom (MDOF) structurs based on the wavelet transform, which has the capacity to detect singularities. First, propagation of discontinuities in the response is investigated qualitatively in order to explain how the structural responses are influenced by sudden changes in structural parameters. Next, the influence of changes of stiffness to the response is quantified. And a method is proposed to connect the wavelet transform to the location of the damage by the state space representation of the MDOF structures. Finally, a simple experiment is carried out to show that the proposed methods are valid in the laboratory-scale structural model reinforced by additional stiffness members. Results of the experiment are showed that the proposed method can identify the existence of small changes in stiffness, but the damage identification is influenced by the way of selections of a sampling frequency and a central frequency of a wavelet.
\end{abstract}

Key Words : Damage Detection, Propagation of Discontinuities, Multi-degree-of-freedam Structures, Wavelet Transform, Sampling Frequency

\section{1. 粕 論}

建築構造物は地震や風などの外的要因によって構 造物内部に稼動不可能に陥るような深刻な損傷が起こ ることがある.これらの損傷の大きさを知ることによ り構造物の余寿命を考え, 適切な対策を考えるという ことはきわめて重要なことである. そこで近年, 稼動 状態において構造物の損傷の有無や大きさを監視する ヘルスモニタリングという考えが必要となっている.

これまで行なわれてきたヘルスモニタリングに関 する研究で, 構造物の損傷検出手法としてウェーブレ ット変換を用いた損傷検出手法が提案されている. こ れらの研究では地震などの繰り返し荷重による低サイ クル疲労を対象とした手法(1) やボルトの破損, 部材の 局所的な座屈など急激な剛性の変化を伴う損傷を対象 にした手法包(4)がある. 本研究では, 後者の損傷を対 象にし損傷に伴って構造物の剛性は急激に変化し, そ

\footnotetext{
* 原稿受付 2006 年 3 月 22 日.

*1 正員, 京都工芸繊維大学大学院工芸科学研究科 (拜 606-8585 京都市左京区松ヶ崎御所海道町).

*2 正員, 京都工芸瀻維大学大学院工芸科学研究科.

E-mail : hashimoto@ viblab.mech.kit.ac.jp
}

の時刻で生じる加速度応答波形に不連続な波形に着目 する. 不連続波形の検出能力を持つウェーブレット変 換を用いてこの不連続波形の発生時刻を常時観測, 常 時検出できれば, 構造物が稼動状態での常時損傷検出 が可能となる.

このウェーブレット変換を用いた損傷検出方法は 1 自由度系モデルで多くなされてきた. しかし，ヘルス モニタリングで対象とする構造物のほとんどは多自由 度構造物であり, この検出手法を多自由度系へ拡張す る必要がある. その際には，損傷の発生時刻だけでな く, 発生箇所も同定できなければならない. そこで, 本研究では, ある箇所での剛性変化に伴って生じる応 答波形内の不連続点が構造物の各点でどのように観測 されるかを次のような二つの手法を基に評価する.

まず, 加速度応答の導関数に注目して, 剛性の不 連続な変化に起因する不連続点が現れる最小の微分階 数を調べることによって加速度応答のウェーブレット 変換值と損傷箇所との関係を定性的に特徴付ける. 次 に, 構造物の状態空間モデルに基づいて, 剛性の不連 続な変化が引き起こす過渡応答を調べることにより, 損傷発生位置と加速度応答のウエーブレット変換值の 
関係を定量的に特徵付ける. また 4 層の構造物モデル を作成し振動実験を行なう.この振動実験により実際 に本研究で提案した手法が有効であることを検証する.

\section{2. ウェーブレット变換による提份検出}

$2 \cdot 1$ ウェープレット变換 関数 $f(t)$ の連続ウ エーブレット変換は $\psi(t)$ をアナライジングウェーブ レットとすると, 次式で与えられる.

$$
(W f(t))(a, b)=\frac{1}{\sqrt{a}} \int_{-\infty}^{\infty} f(t) \bar{\psi}\left(\frac{t-b}{a}\right) d t
$$

ここで, 実数 $a, b$ は, それぞれスケールパラメータ, シフトパラメータであり, $\bar{\psi}(t)$ は $\psi(t)$ の複素共役を 表す. また, アナライジングウェーブレット $\psi(t)$ は 次式のような許容条件を満たす必要がある.

$$
C_{\psi}=\int_{-\infty}^{\infty} \frac{|\hat{\psi}(\omega)|^{2}}{\omega} d \omega<\infty
$$

ここで, $\hat{\psi}(\omega)$ は $\psi(t)$ のフーリ工変換を表す.

本研究では, アナライジンクウェーブレットとして, 次式で表される Gaussian の 4 階微分に $(-1)^{4}$ を掛けた ものを用いる.

$$
\psi_{4}=(-1)^{4} \frac{\partial^{4} \phi(t)}{\partial t^{4}}, \phi(t)=e^{\frac{-t^{2}}{2}}
$$

このアナライジングウェーブレットは 0～3 次までの モーメントが 0 となる. つまり, 4 個のバニシングモ 一メントを持つ(5.

$$
\int_{-\infty}^{\infty} t^{m} \psi(t) d t=0 \quad(0 \leq m \leq 3)
$$

この性質を用いると, ウェーブレット変換は波形その もの，またはその導関数に含まれる不連続点を検出で きる. ただし，初めて不連続点がでる導関数の階数が 大きいほど検出は難しくなる.

$2 \cdot 2$ 損住検出例 まず, $2 \cdot 1$ 節で述べたウェー ブレット変換を用いて, 図 1 の 4 自由度構造物モデル での損傷検出例を示す. 入力加速度 $\ddot{x}_{g}(t)$ は ElCentro 地震波を用いる.ここで, モデルのパラメー夕は $m_{1}=m_{2}$ $=m_{3}=m_{4}=2000[\mathrm{~kg}], k_{1}=k_{3}=k_{4}=1 \times 10^{6}[\mathrm{Nm}], c_{1}=c_{2}=c_{3}$ $=c_{4}=500[\mathrm{Nsm}]$ であり, $k_{2}(t)$ の初期 $1 \times 10^{6}[\mathrm{Nm}]$ である. また, サンプリング周波数は50 [Hz]であり, ウェーブレッ トの中心周波数は22 [Hz]としている. 損傷位置は 1 層 目と 2 層目の間とし剛性パラメータ $k_{2}(t)$ が損傷時刻 $t_{c}$ で5\%低下すると考える. また，損傷時刻は 5.26秒で ある. 図2にこのシミュレーション結果を示す.

この結果よりウェーブレット変換値は損傷箇所に 最も近い位置で最も大きく，外側の層にいくにつれて

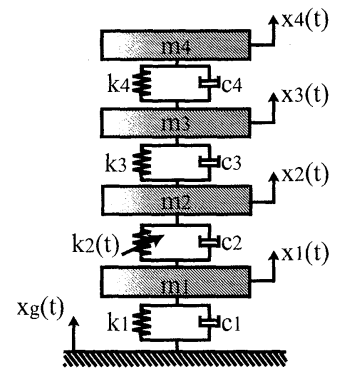

Fig.1 Structural model

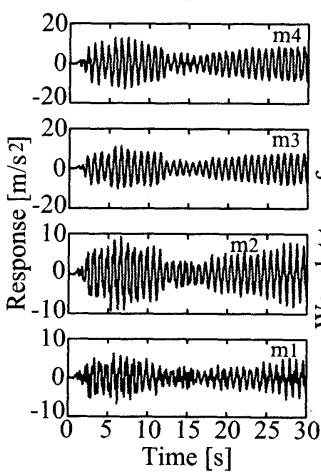

(a) Response

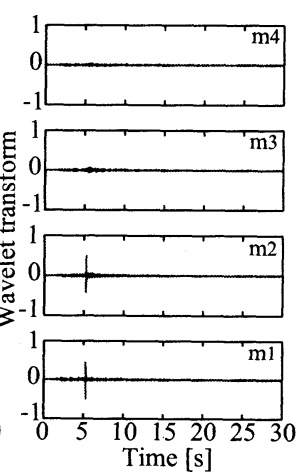

(b) Wavelet transform
Fig.2 Consequences of the Simulation 小さくなっていくことがわかる. この結果は損傷によ る不連続性が各層に伝播していることを示すものであ る. そこでこの不連続性がどのように各層に伝播して いくかを次章で定性的に検討していく.

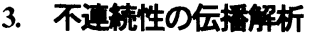

剛性が不連続に変化すると, 絶対加速度応答, また はその導関数に不連続性か現れる. ここでは, 剛性の 変化に起因する不連続性が構造物内を空間的にどのよ うに伝播していくかを定性的に解析するとして, 図 1 で示した単純な 4 自由度構造物モデルを用いる. また, 損傷位置は 1 層目と 2 層目の間とし剛性パラメー夕 $k_{2}(t)$ が損傷時刻 $t_{c}$ で変化すると考える. このモデル の運動方程式は次式のようになる.

$$
\begin{aligned}
& {\left[M_{0}\right]\left\{\ddot{x}_{a}(t)\right\}+\left[C_{0}\right]\{\dot{x}(t)\}+\left[K_{0}(t)\right]\{x(t)\}=0} \\
& \{x(t)\}=\left\{x_{a}(t)\right\}-\left\{x_{g}(t)\right\} \\
& {\left[M_{0}\right]=\left[\begin{array}{cccc}
m_{1} & 0 & 0 & 0 \\
0 & m_{2} & 0 & 0 \\
0 & 0 & m_{3} & 0 \\
0 & 0 & 0 & m_{4}
\end{array}\right], \quad\left[C_{0}\right]=\left[\begin{array}{cccc}
c_{1}+c_{2} & c_{2} & 0 & 0 \\
c_{2} & c_{2}+c_{3} & c_{3} & 0 \\
0 & c_{3} & c_{3}+c_{4} & c_{4} \\
0 & 0 & c_{4} & c_{4}
\end{array}\right],}
\end{aligned}
$$




$$
\begin{aligned}
& {\left[K_{0}(t)\right]=\left[\begin{array}{cccc}
k_{1}+k_{2}(t) & k_{2}(t) & 0 & 0 \\
k_{2}(t) & k_{2}(t)+k_{3} & k_{3} & 0 \\
0 & k_{3} & k_{3}+k_{4} & k_{4} \\
0 & 0 & k_{4} & k_{4}
\end{array}\right]} \\
& k_{2}(t)= \begin{cases}k_{2} & 0 \leq t<t_{c} \\
k_{2}(1-\eta) & t \geq t_{c}\end{cases}
\end{aligned}
$$

ここで, $\left[M_{0}\right],\left[C_{0}\right],\left[K_{0}(t)\right]$ は質量行列, 減衰行列, 剛性行列を表し, $x_{a}(t), x(t), x_{g}(t)$ は絶対変位, 相対変位, 入力変位を表す.

式（5）を変形すると, 次式のようになる.

$$
\begin{aligned}
& \left\{\ddot{x}_{a}(t)\right\}=[C]\{\dot{x}(t)\}+[K(t)]\{x(t)\} \\
& {[C]=-\left[M_{0}\right]^{-1}\left[C_{0}\right], \quad[K(t)]=-\left[M_{0}\right]^{-1}\left[K_{0}(t)\right]}
\end{aligned}
$$

$2 \cdot 1$ 節で述べたようにウェーブレット変換は, 波 形そのもの, またはその導関数に含まれる不連続点を 検出できる. そこで, 損傷に伴う不連続量が各層の絶 対加速度応答にどのように出現するかをみるために, 式（6）を 1 階微分したものと 2 階微分したものを次 式に示す.

$$
\begin{aligned}
&\left\{\ddot{x}_{a}^{(1)}(t)\right\}= {[C]\{\ddot{x}(t)\}+[K(t)]\{\dot{x}(t)\}+[\dot{K}(t)]\{x(t)\} } \\
&=([C][C]+[\dot{K}(t)])\{\dot{x}(t)\} \\
&+\{[C][K(t)]+[\dot{K}(t)]\}\{x(t)\}-[C]\left\{\ddot{x}_{g}(t)\right\} \\
&\left\{\ddot{x}_{a}^{(2)}(t)\right\}=[C]\{\ddot{x}(t)\}+[K(t)]\{\ddot{x}(t)\}+2[\dot{K}(t)]\{\dot{x}(t)\} \\
&+[\ddot{K}(t)]\{x(t)\} \\
&=\{([C][C]+[K(t)])[C]+[C][K(t)]+2[\dot{K}(t)]\}\{\dot{x}(t)\} \\
&+\{([C][C]+[K(t)])[K(t)]+[\dot{K}(t)]+[\ddot{K}(t)]\}\{x(t)\} \\
&-\left\{([C][C]+[K(t)])\left\{\ddot{x}_{g}(t)\right\}+[C]\left\{\ddot{x}_{g}(t)\right\}\right\}
\end{aligned}
$$

また, $n$ 層目の岡性が損傷に伴って減少したとすると, $k_{n}(t)$ が損傷時刻 $t_{c}$ で不連続となり, さらに $k_{n}(t)$ の影 響により $m$ 層目の絶対加速度応答も損傷時刻 $t_{c}$ で不 連続となる. また, $k_{n}(t)$ を $l$ 階微分したものを $k_{n}^{(l)}(t)$ とおき，これらの不連続量をそれぞれ次式で評価する.

$$
\begin{aligned}
& \left\{\Delta k_{n}\left(t_{c}\right)\right\}=\left\{k_{n}^{+}\left(t_{c}\right)\right\}-\left\{k_{n}^{-}\left(t_{c}\right)\right\} \quad(n=1,2,3,4) \\
& \left\{\Delta \ddot{x}_{a m}\left(t_{c}\right)\right\}=\left\{\ddot{x}_{a m}^{+}\left(t_{c}\right)\right\}-\left\{\ddot{x}_{a m}^{-}\left(t_{c}\right)\right\} \quad(m=1,2,3,4) \\
& \left\{\Delta k_{n}^{l}\left(t_{c}\right)\right\}=\left\{k_{n}^{(l)+}\left(t_{c}\right)\right\}-\left\{k_{n}^{(l)-}\left(t_{c}\right)\right\}(l=1,2, \cdots) \\
\text { ここで, } & \alpha^{+}\left(t_{c}\right), \quad \alpha^{-}\left(t_{c}\right)\left(\alpha=\Delta k_{n}, \Delta x_{a m}, \Delta k_{n}^{(l)}\right) \text { は }
\end{aligned}
$$

である。

今, 図 1 のように損傷に伴って 2 層目の剛性が減 少したとすると, パラメータ $k_{2}(t)$ は損傷時刻 $t_{c}$ で不 連続となる. このとき, 各層の絶対加速度応答にどの ような不連続性が現れるかをみる.

ある応答波形の $n$ 階導関数がある時刻で不連続点 を持つ場合, $n+1$ 階以降の導関数はこの時刻では存
在しない。つまり，式（6），式（7)，式（8）にお いて, 各層の応答波形を $n$ 階微分していく過程で, 最 初に不連続量が現れる微分階数に着目する必要がある. このことを考慮すると, 損偒時刻 $t_{c}$ での各層の絶対加 速度応答の不連続量に関する項は, 次のようになる.

$$
\begin{aligned}
& \Delta \ddot{x}_{a 1}\left(t_{c}\right)=\frac{\Delta k_{2}\left(t_{c}\right)}{m_{1}}\left\{-x_{1}\left(t_{c}\right)+x_{2}\left(t_{c}\right)\right\} \\
& \Delta \ddot{x}_{a 2}\left(t_{c}\right)=\frac{\Delta k_{2}\left(t_{c}\right)}{m_{2}}\left\{x_{1}\left(t_{c}\right)-x_{2}\left(t_{c}\right)\right\} \\
& \Delta \ddot{x}_{a 3}^{(1)}\left(t_{c}\right)=\frac{\Delta k_{2}\left(t_{c}\right)}{m_{3}} \frac{c_{3}\left(t_{c}\right)}{m_{2}}\left\{x_{1}\left(t_{c}\right)-x_{2}\left(t_{c}\right)\right\} \\
& \Delta \ddot{x}_{a 4}^{(2)}\left(t_{c}\right)=\frac{\Delta k_{2}\left(t_{c}\right)}{m_{4}} \frac{c_{3}\left(t_{c}\right) c_{4}\left(t_{c}\right)}{m_{2} m_{3}}\left\{x_{1}\left(t_{c}\right)-x_{2}\left(t_{c}\right)\right\}
\end{aligned}
$$

これより，1 層目， 2 層目は絶対加速度応答で損傷 による不連続量の影響を受け，3 層目は絶対加速度の 1 階微分に, 4 層目は絶対加速度の 2 階微分に影響を 受ける. このことより, 損傷による不連続性は微分階 数が 1 階増えるごとに 1 層外側に伝播していくと考え られる.また，2・1 節で述べたように不連続になる 導関数の階数が大きいほどウェーブレット変換値の絶 対値は小さくなると考えられる. よって損傷位置から 遠くなるほど加速度応答のウエーブレット変換値は小 さくなる. このことより, 損傷時刻で各層のウェーブ レット変換值を比較することにより損傷位置の同定が 可能となる。

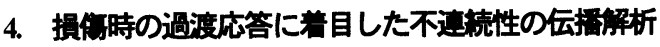

4・1 賣场による過渡応答＼cjkstart第3章では損傷に伴 う剛性の変化量を不連続量として, この不連続量がど のように伝播いていくかを検討し，損傷箇所に最も近 い位置でウェーブレット変換值は最も大きく，外側の 層にいくにつれて小さくなっていくという結果が得ら れた. しかし, この結果は定性的なものであり, 各層 のパラメー夕值の影響やモデルによる違いの詳細は不 明である. 例えば, 同じ 4 層構造物でも, 図 1 のよう な単純なモデルと層間部材のダイナミクスまで考慮し た図3のようなモデルが考えられるが, 後者の中間質 量を 0 に漸近させれば, 後者は前者に一致する. すな わち, どちらも同じダイナミクスを表現できるはずで ある. ところが前節の定性的な議論だと，例えば中間 質量を 0 に漸近させたとしても前者における不連続性 の伝播範囲と後者における伝播範囲は異なるというこ とになってしまう. これは矛盾であり, 前節の議論の 限界を示すものである.

そこでこの節では, 剛性の不連続な変化が加速度 応答に及ぼす影響を定量的に評価する.これにより， 

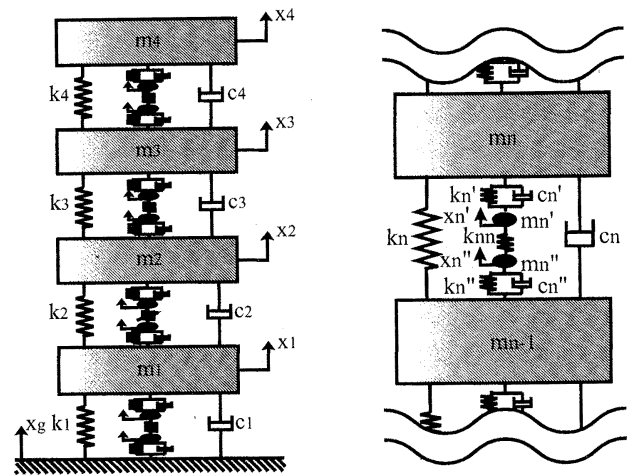

(a) Structural model with (b) Detail of the structural mode medium masses with medium masses

Fig.3 Structural model with medium masses

構造物における質量分布の影響や，モデルの局所的な 特徵の影響などを詳細に議論することが可能になる. 対象とする構造物モデルは図 1 のモデルである. このモデルにおいて時刻 $t_{c}$ で損傷により剛性パラメ 一夕 $k_{2}(t)$ が $k_{2}$ から $k_{d 2}$ に低下したとし, 損傷前と損傷 後に状態を分け状態空間モデルを書く.

[損傷前の状態空間モデル]

$$
\begin{aligned}
& \{\dot{x}(t)\}=\mathbf{A}\{x(t)\}+\mathbf{b} u(t) \quad\left(0 \leq t<t_{c}\right) \\
& \{y(t)\}=\mathbf{c}\{x(t)\} \\
& \{x(0)\}=[0,0,0,0,0,0,0,0]^{T} \\
& \{x(t)\}=\left[x_{1}, x_{2}, x_{3}, x_{4}, \dot{x}_{1}, \dot{x}_{2}, \dot{x}_{3}, \dot{x}_{4}\right]^{T}, \quad u(t)=\ddot{x}_{g}(t), \\
& \mathbf{A}=\left[\begin{array}{cc}
\mathbf{0} & \mathbf{I} \\
\mathbf{K} & \mathbf{D}
\end{array}\right], \quad \mathbf{c}=\left[\begin{array}{ll}
\mathbf{K} & \mathbf{D}
\end{array}\right] \\
& \mathbf{b}=[0,0,0,0,-1,-1,-1,-1]^{T} \\
& \mathbf{K}=\left[\begin{array}{cccc}
-\frac{k_{1}+k_{2}}{m_{1}} & \frac{k_{2}}{m_{1}} & 0 & 0 \\
\frac{k_{2}}{m_{2}} & -\frac{k_{2}+k_{3}}{m_{2}} & \frac{k_{3}}{m_{2}} & 0 \\
0 & \frac{k_{3}}{m_{3}} & -\frac{k_{3}+k_{4}}{m_{3}} & \frac{k_{4}}{m_{3}} \\
0 & 0 & \frac{k_{4}}{m_{4}} & -\frac{k_{4}}{m_{4}}
\end{array}\right] \\
& \mathbf{D}=\left[\begin{array}{cccc}
-\frac{c_{1}+c_{2}}{m_{1}} & \frac{c_{2}}{m_{1}} & 0 & 0 \\
\frac{c_{2}}{m_{2}} & -\frac{c_{2}+c_{3}}{m_{2}} & \frac{c_{3}}{m_{2}} & 0 \\
0 & \frac{c_{3}}{m_{3}} & -\frac{c_{3}+c_{4}}{m_{3}} & \frac{c_{4}}{m_{3}} \\
0 & 0 & \frac{c_{4}}{m_{4}} & -\frac{c_{4}}{m_{4}}
\end{array}\right]
\end{aligned}
$$$$
\{y(t)\}=\left[\ddot{x}_{a 1}, \ddot{x}_{a 2}, \ddot{x}_{a 3}, \ddot{x}_{a 4}\right]^{T}, \quad \ddot{x}_{a n}=\ddot{x}_{n}+\ddot{x}_{g}(n=1,2,3,4)
$$

式（17）, 式（18）より,

$$
\{y(t)\}=\int_{0}^{t} \mathbf{c} e^{\mathbf{A}(t-\tau)} \mathbf{b} u(\tau) d \tau \quad\left(0 \leq t<t_{c}\right)
$$

\section{[損傷後の状態空間モデル]}

$$
\begin{aligned}
& \left\{\dot{x}_{d}(t)\right\}=\mathbf{A}_{\mathbf{d}}\left\{x_{d}(t)\right\}+\mathbf{b} u(t) \quad\left(t \geq t_{c}\right) \\
& \left\{y_{d}(t)\right\}=\mathbf{c}_{\mathbf{d}}\left\{x_{d}(t)\right\} \\
& \left\{x_{d}(t)\right\}=\left[x_{d 1}, x_{d 2}, x_{d 3}, x_{d 4}, \dot{x}_{d 1}, \dot{x}_{d 2}, \dot{x}_{d 3}, \dot{x}_{d 4}\right]^{T} \\
& \left\{y_{d}(t)\right\}=\left[\ddot{x}_{a d 1}, \ddot{x}_{a d 2}, \ddot{x}_{a d 3}, \ddot{x}_{a d 4}\right]^{T} \\
& \ddot{x}_{a d n}=\ddot{x}_{d n}+\ddot{x}_{g}(n=1,2,3,4) \\
& \mathbf{A}_{\mathrm{d}}=\left[\begin{array}{cc}
\mathbf{0} & \mathbf{I} \\
\mathbf{K}_{\mathrm{d}} & \mathbf{D}
\end{array}\right], \quad \mathbf{c}_{\mathbf{d}}=\left[\begin{array}{ll}
\mathbf{K}_{\mathrm{d}} & \mathbf{D}
\end{array}\right]
\end{aligned}
$$$$
\mathbf{K}_{\mathbf{d}}=\left[\begin{array}{cccc}
-\frac{k_{1}+k_{d 2}}{m_{1}} & \frac{k_{d 2}}{m_{1}} & 0 & 0 \\
\frac{k_{d 2}}{m_{2}} & -\frac{k_{d 2}+k_{3}}{m_{2}} & \frac{k_{3}}{m_{2}} & 0 \\
0 & \frac{k_{3}}{m_{3}} & -\frac{k_{3}+k_{4}}{m_{3}} & \frac{k_{4}}{m_{3}} \\
0 & 0 & \frac{k_{4}}{m_{4}} & -\frac{k_{4}}{m_{4}}
\end{array}\right]
$$

式 (20)，（21）より,

$$
\begin{aligned}
\left\{y_{d}(t)\right\}= & \mathbf{c}_{\mathbf{d}} e^{\mathbf{A}_{\mathbf{d}}\left(t-t_{c}\right)}\left\{x\left(t_{c}\right)\right\} \\
& +\int_{t_{c}}^{t} \mathbf{c}_{\mathbf{d}} e^{\mathbf{A}_{\mathbf{d}}\left(\left(t-t_{c}\right)-\tau\right)} \mathbf{b} u(\tau) d \tau \quad\left(t \geq t_{c}\right)
\end{aligned}
$$

もし，損傷が起こらなかったと仮定すると，

$$
\begin{aligned}
\{y(t)\}= & \mathbf{c} e^{\mathbf{A}\left(t-t_{c}\right)}\left\{x\left(t_{c}\right)\right\} \\
& +\int_{t_{c}} \mathbf{c} e^{\mathbf{A}\left(\left(t-t_{c}\right)-\tau\right)} \mathbf{b} u(\tau) d \tau \quad\left(t \geq t_{c}\right)
\end{aligned}
$$

ここで, 損傷が起こらないと仮定した式を基準の応答 と考え，損傷による過渡応答を評価する. 式 (22) , 式（23）より，損傷に関する項である初期值応答は第 1 項なので, 第 1 項のみを考虑すると, 損傷により起 こる過渡応答は次式のように表せる.

$$
\begin{aligned}
\{f(t)\} & =\left\{y_{d}(t)\right\}-\{y(t)\} \\
& =\mathbf{c}_{\mathbf{d}} e^{\mathbf{A}_{\mathbf{d}}\left(t-t_{c}\right)}\left\{x\left(t_{c}\right)\right\}-\mathbf{c} e^{\mathbf{A}\left(t-t_{c}\right)}\left\{x\left(t_{c}\right)\right\} \quad\left(t \geq t_{c}\right) \\
& =\left(\mathbf{c}_{\mathbf{d}} e^{\mathbf{A}_{\mathbf{d}}\left(t-t_{c}\right)}-\mathbf{c} e^{\mathbf{A}\left(t-t_{c}\right)}\right)\left\{x\left(t_{c}\right)\right\}
\end{aligned}
$$

式 (24) より, $\left(c_{d} e^{\Lambda_{d}\left(t-t_{e}\right)}-c e^{A_{\left(l-t_{e}\right)}}\right)$ の行列要素は損傷時 の過渡応答波形の形を表していることがわかる.これ より, $n$ 自由度モデルで考えると, 次式となる.

$$
\begin{aligned}
{\left[c_{d}\right] e^{\left[A_{d}\right]\left(t-t_{c}\right)}-[c] e^{[A]\left(t-t_{c}\right)} } & \\
= & {\left[\begin{array}{cccc}
a_{11}\left(t-t_{c}\right) & a_{12}\left(t-t_{c}\right) & \cdots & a_{1 n}\left(t-t_{c}\right) \\
a_{21}\left(t-t_{c}\right) & a_{22}\left(t-t_{c}\right) & & \vdots \\
\vdots & & \ddots & \vdots \\
a_{n 1}\left(t-t_{c}\right) & \cdots & \cdots & a_{n n}\left(t-t_{c}\right)
\end{array}\right] }
\end{aligned}
$$


ここで, $a_{l m}(l=1,2 \cdots, n),(m=1,2 \cdots, n)$ は $l$ 層目に対 する $m$ 層目の過渡応答成分である.

$\mathbf{4} \cdot \mathbf{2}$ 不速橖性の検出可能性の見稹もり 損傷時 刻 $t_{c}$ において, 加速度観測值が，例えば図 4 (a) の ような不連続性を持つ場合, これのウェーブレット変 換值により不連続性を検出できるためには損傷時刻近 傍におけるウェーブレット変換值の振幅が, その後の 時刻におけるウェーブレット変換值の振幅より十分大 きくなければならない.つまり, 図4 (a) の $P_{1}$ と $P_{2}$ の比, すなわち, 次式で表される波高率 $R$ が 1 より十 分大きいことが必要である.

$$
R=\frac{\max _{t_{c}-\varepsilon / 2 \leq b \leq t_{c}+\varepsilon / 2}|(W y)(a, b)|}{\max _{t_{c}+\varepsilon / 2 \leq b \leq t_{c}+\varepsilon / 2+\varepsilon_{1}}|(W y)(a, b)|} \gg 1
$$

損傷の検出可能性を評価するために, 各観測点に おける応答のウェーブレット変換の波高率 $R$ をシス テムの支配方程式から見積もることを試みる.

まず，損傷時刻 $t_{c}$ 近傍 $\left(t_{c}-\varepsilon \leq t \leq t_{c}+\varepsilon\right)$ において, 観測ベクトル $\{y(t)\}$ を次式のように表現する.

$$
\{y(t)\}=\left\{y_{u}(t)\right\}+\{\Delta y(t)\} \quad\left(t_{c}-\varepsilon / 2 \leq t<t_{c}+\varepsilon / 2\right)
$$

ただし，

$$
\{\Delta y(t)\}=\left\{\begin{array}{lc}
0 & \left(t_{c}-\varepsilon / 2 \leq t<t_{c}\right) \\
\left\{y_{d}(t)\right\}-\left\{y_{u}(t)\right\} & \left(t_{c} \leq t<t_{c}+\varepsilon / 2\right)
\end{array}\right.
$$

ここで, $\left\{y_{u}(t)\right\}$ は損傷していないシステムの応答, $\left\{y_{d}(t)\right\}$ は損傷したシステムの応答である. これより 式(27)の $\left\{y_{u}(t)\right\}$ は $t_{c}$ の前後で滑らかにつながるので,

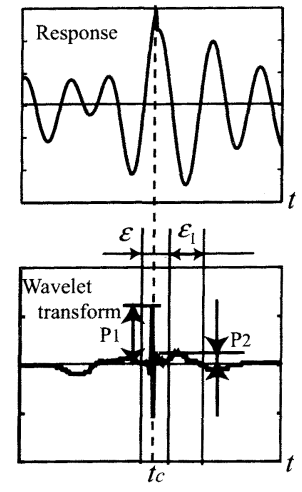

(a) Response and wavelet transform

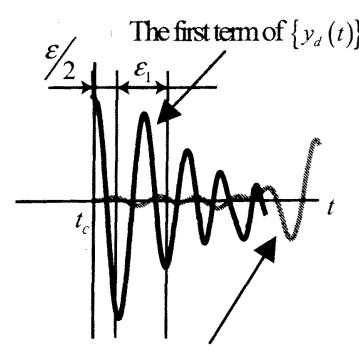

The second term of $\left\{y_{d}(t)\right\}$
Fig.4 Response and wavelet transform around the time of the damage $\{y(t)\}$ のウェーブレット変換值は $\Delta y$ のウェーブレッ 卜変換値に支配され, 次式のようになる.

$$
(W y)(a, b) \simeq(W \Delta y)(a, b) \quad(a \ll 1)
$$

今, $t \geq t_{c}$ における $\left\{y_{u}(t)\right\},\left\{y_{d}(t)\right\}$ は,

$$
\begin{aligned}
& \left\{y_{u}(t)\right\}=\mathbf{c} e^{\mathbf{A}\left(t-t_{c}\right)}\left\{x\left(t_{c}\right)\right\}+\int_{t_{c}}^{t} \mathbf{c} \mathbf{e}^{\mathbf{A}(t-\tau)} \mathbf{b} u(\tau) d \tau \\
& \left\{y_{d}(t)\right\}=\mathbf{c}_{\mathbf{d}} e^{\mathbf{A}_{\mathbf{d}}\left(t-t_{c}\right)}\left\{x\left(t_{c}\right)\right\}+\int_{t_{c}}^{t} \mathbf{c}_{\mathbf{d}} e^{\mathbf{A}_{\mathbf{d}}(t-\tau)} \mathbf{b} u(\tau) d \tau(31)
\end{aligned}
$$

となるので, $\{\Delta y(t)\}$ は次式のように書き換えられる.

$$
\begin{aligned}
& \{\Delta y(t)\}= \begin{cases}0 & \left(t_{c}-\varepsilon / 2 \leq t<t_{c}\right) \\
\Delta\left(t-t_{c}\right)\left\{x\left(t_{c}\right)\right\} & \\
+\int_{t_{c}}^{t} \Delta\left(t-t_{c}\right) \mathbf{b} u(\tau) d \tau & \left(t_{c} \leq t<t_{c}+\varepsilon / 2\right)\end{cases} \\
& \Delta(t)=\mathbf{c}_{\mathbf{d}} e^{\mathbf{A}_{\mathbf{d}}(t)}-\mathbf{c} e^{\mathbf{A}(t)}
\end{aligned}
$$

損傷時刻 $t_{c}$ 近傍では, 式(25)の過渡応答項の不連続性 のほうが第2 項より支配的だと考えると, 式（29）は

$$
(W y)(a, b) \simeq(W \Delta)(a, b) x\left(t_{c}\right) \quad(a \ll 1)
$$

となる. したがって，不連続を表すスパイク波形の最 大振幅は,

$$
\max _{t_{c}-\varepsilon / 2 \leq b \leq t_{c}+\varepsilon / 2}|(W y)(a, b)|=\max _{t_{c} \leq b \leq t_{c}+\varepsilon / 2}\left|(W \Delta)(a, b)\left\{x\left(t_{c}\right)\right\}\right|
$$

と見積もることができる.

$$
(a \ll 1)
$$

次に, 損傷時刻 $t_{c}$ 近傍領域 $\left(t_{c}-\varepsilon / 2 \leq t \leq t_{c}+\varepsilon / 2\right)$ 以 降の応答のウェーブレット変換は, $\boldsymbol{\Phi}_{\mathbf{d}}(t):=\mathbf{c}_{\mathbf{d}} e^{\mathbf{A}_{\mathbf{d}}(t)}$ とおくと,

$$
\begin{aligned}
\left(W\left\{y_{d}(t)\right\}\right)(a, b) & =\left(W \boldsymbol{\Phi}_{\mathbf{d}}\right)(a, b)\left\{x\left(t_{c}\right)\right\} \\
& +\left(W\left\{\int_{c} \boldsymbol{\Phi}_{\mathbf{d}}(t-\tau) \mathbf{b} u(\tau) d \tau\right\}\right)(a, b)
\end{aligned}
$$

であるが, 図 4 (b) のように $t_{c} \leq t \leq t_{c}+\varepsilon / 2+\varepsilon_{1}$ の領 域で式（35）の第2 項はほとんど0であることを考慮 すると, 振幅の最大值は次式のように評価できる.

$$
\begin{array}{r}
\max _{t_{c}+\varepsilon / 2 \leq b \leq t_{c}+\varepsilon / 2+\varepsilon_{1}}|(W y)(a, b)|=\max _{t_{c} \leq b \leq t_{c}+\varepsilon / 2+\varepsilon_{1}}\left|\left(W \boldsymbol{\Phi}_{\mathbf{d}}\right)(a, b)\left\{x\left(t_{c}\right)\right\}\right| \\
(a \ll 1) \quad(36)
\end{array}
$$

以上のことを考慮して,$m$ 層目の応答観測值のウェ 一ブレット変換值の損傷時における波高率 $R$ を近似 的に評価する量として, 本研究では損偟検出可能性指 標 $\delta_{m}$ を次式のように定義する.

$$
\delta_{m}=\frac{\max _{n}\left[\max _{t_{c} \leq b \leq t_{c}+\varepsilon / 2}|(W \Delta)(a, b)|\right]_{m n}}{\max _{n}\left[\max _{t_{c} \leq b \leq t_{c}+\varepsilon / 2+\varepsilon_{1}}\left|\left(W \boldsymbol{\Phi}_{\mathbf{d}}\right)(a, b)\right|\right]_{m n}} \quad(a \ll 1)
$$




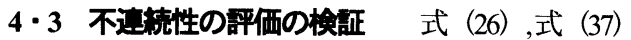
を用いて, 数值的な検証を行なう. 本研究では, $4 \cdot 1$ 節の式 (25) である $\left(\mathbf{c}_{\mathrm{d}} e^{\mathbf{A}_{\mathrm{d}}\left(t-t_{c}\right)}-\mathbf{c} e^{\mathbf{A}\left(t-t_{c}\right)}\right)$ を数值的に解 き, 行列要素それぞれの応答波形のウエーブレット変 換值によって不連続性の伝播状況を確認する. 対象と する構造物モデルは図 1 , 図3 の構造物モデルを用い る. 図3の構造物モデルは主の質量部分とその下にあ る 2 つの中間質量部の質量との和が図 1 のモデルの質 量部分に対応する. ここで, $k_{n n}=k_{n}^{\prime}=k_{n}^{n}(n=1,2,3,4)$ であり, 損傷時に $k_{n n}$ が 0 となる. つまり, 損傷後剛 性要素は $k_{n}$ のみとなる.

まず，図 1 に示す構造物モデルを用いた結果を図 5 に示す. 図 5 は行列要素の各行における損傷検出可能 性指標の最大值を棒グラフにして示している. 損傷検 出可能限界は 1 としているが横軸に対数をとっている

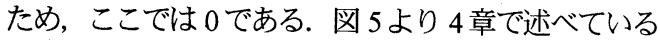
定量的な評価方法でも, 図 1 に示す単純な構造物モデ ルにおいて, 損傷に伴う不連続波は損傷位置の最も近 い位置でウェーブレット変換値は最も大きくなり外側 の層にいくにつれて徐々に小さくなっていくという 3 章の定性的な議論を確認できる結果となっている.

次に, モデル化の違いによる影響をみるため図 3 の構造物モデルを用いても検証した. 中間質量部分の 大きさを総重量の $1 / 100$ したものモデルでの結果を図 6に示し，1/3にしたモデルでの結果を図 7 に示す.

まず, モデル化の違いによる影響を図 5, 図 6 から みると; 図 6 では質量分布が同じでもモデル化の違い で図 5 とは異なり, より詳細な不連続性の伝播状況を 示している. さらに, 図 6, 図 7から質量分布に関し て検討すると, 中間質量が大きくなれば不連続性の伝 播が悪くなっている. また, 図 6, 図 7 に示す構造物 モデルには主の質量部分と主の質量部分の間にバネと ダッシュポットがあるため, 中間質量部分を飛び越え て主の質量に不連続性が伝播するなどの現象が見て取

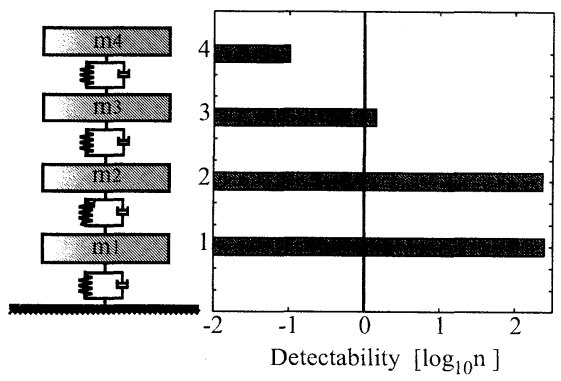

Fig.5 Detectability of the structural model shown in Fig.1

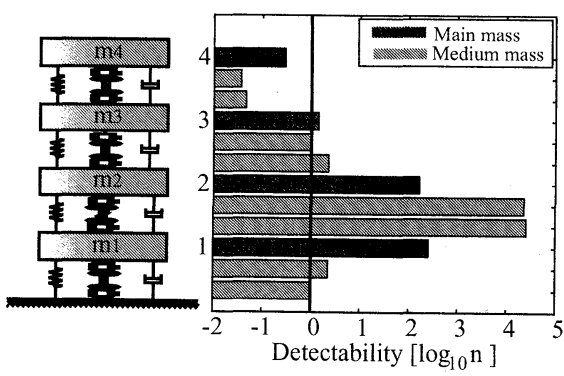

Fig.6 Detectability of the structural model shown in Fig.3 (1/100)

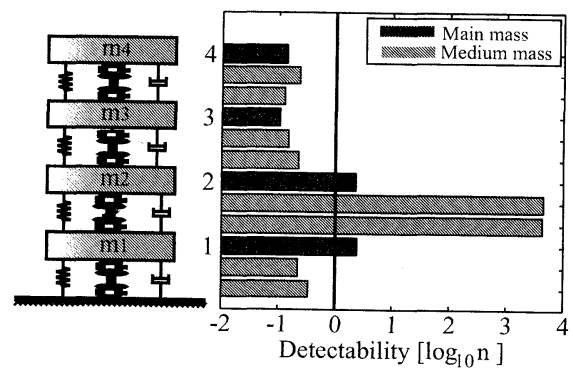

Fig.7 Detectability of the structural model shown in Fig.3 (1/3)

れる.これより，4 章で示す定量的な議論では，構造 物のモデル化によってはそのモデルの質量配分やバネ, ダッシュポットの配置により変化する不連続波の伝播 状況を可視化し確認することが可能となった。 また， すべてのモデルにおいて損傷検出可能限界である 1 以上 であるメイン質量部分の損傷検出可能性指標をみると, 值は損傷部分に最も近い位置で最も大きく, 外側に行く につれて小さくなっている. これより，3章の定性的な 議論はモデル化の違いに影響を受けないことがわかる.

\section{5. 振动実験による検佂}

$5 \cdot 1$ 実験摡要ここ章では上の章で述べたウェ ーブレット変換による損傷同定手法を実験的に検証す る. 構造物模型（図 8）は各層にバネを介したブレ一 スを張った 4 層からなる多自由度構造物である. 構造 物模型に与える模擬的な損傷として, ブレース部分の 破断を考える. ここで, 各ブレースは金属棒で作られ ており, 途中に柔らかいバネが挿入されている. した がって, ブレースの剛性はこのバネによって決められ ている. まず，損傷を模擬する部分に電磁石と鉄板を 用いてブレースを結合しておく. そして, ある時刻で 電磁石の電流を切ることにより電磁石と鉄板を切り離 し,この時刻を損傷発生時刻とみなす.この損傷発生 


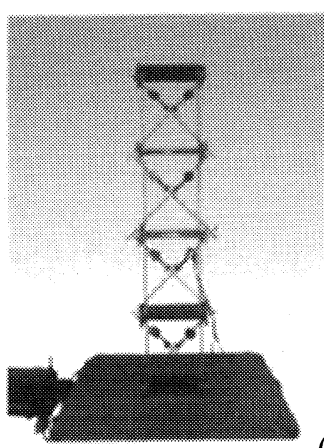

(b) Detail of the experimental (a) Experimental model

Fig.8 Experimental setup
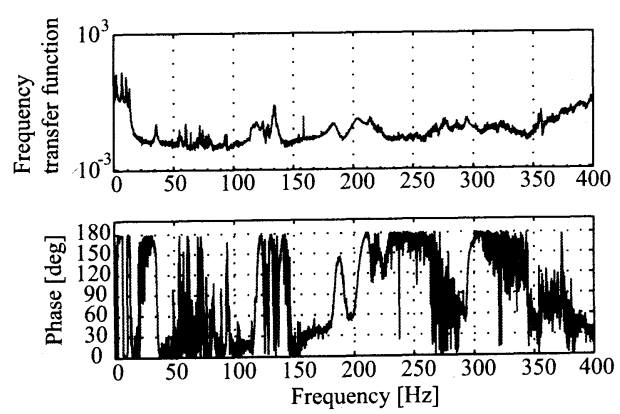

Fig.9 Bode diagram

時刻はトリガによって計測しておく，また，すべての 層で動特性が同じになるように, 損傷モデルを含む層 以外の層のブレースにも電磁石と同じ質量を持つ質量 を取り付けている. さらに, 予備実験によりブレース の破断によってバネ定数の減少率は $1.5 \%$ \%あること がわかっている. サンプリング周波数は, 図 9 を参考 にして 4次モードまでが含まれる $20[\mathrm{~Hz}]$ の 10 倍であ る $200[\mathrm{~Hz}]$ とした. また, 本振動実験で用いた入力波 形は広帯域有色雑音であり, 損傷位置はここでは 1 層 目と 2 層目の間としている.

$5 \cdot 2$ 実鈋吉果上で述べた条件の基で計測した 加速度応答波形を図 10 (a) に示す. 図 10 (a) は上 のグラフから 4 層目, 3 層目, 2 層目， 1 層目の加速 度応答波形の順に並んでおり, 最下部のグラフはトリ ガ波形を示している. また，図 10 (a) の加速度応答 波形のウエーブレット変換值を図 10 (b) に加速度波 形と同様の順序で示す.この結果より加速度応答波形 では損傷時刻で損傷の兆候がみられないのに対し，ウ エーブレット変換值では他の時刻より損傷時刻で相対 的に大きくなり損傷時刻を示している. さらに, 損傷 部分であるブレースの両側の層, つまり 1 層目と 2 層 目のウェーブレット変換值は大きくなり, さらに外側

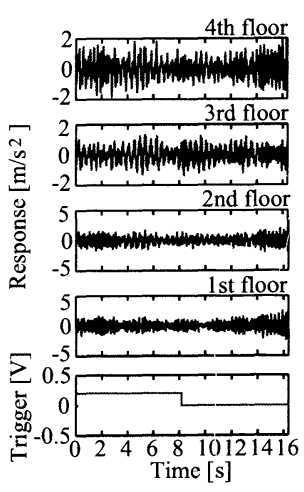

(a) Responses

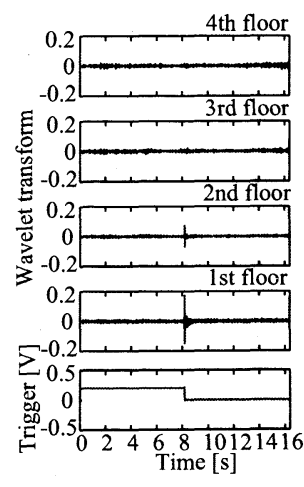

(b) Wavelet transforms
Fig.10 Consequences of the experiment (Sampling frequency 200[Hz])

の層ではウェーブレット変換値は内側の層より相対的 に小さくなっており, よく損傷の同定ができている.

$5 \cdot 3$ サンプリング周波数について 本研究では サンプリング周波数を $200[\mathrm{~Hz}]$ とした. しかし, ウェ 一ブレット変換の理論ではスケールが小さいほど, す なわちウェーブレットの中心周波数を大きくすればす るほど，不連続波形の検出能が向上する. そこで，ウ エーブレットの中心周波数を大きくするために, サン プリング周波数を大きく取るとウェーブレット変換の 検出能がどのようになるのかを検討する．ここで，用 いたサンプリング周波数は $500[\mathrm{~Hz}], 1000[\mathrm{~Hz}]$ あ゙ある. また, ウェーブレットのスケールとサンプリング周波 数との関係は, 次式で与える.

$$
a=\frac{1}{f_{s}}
$$

ここで, $a$ はアナライジングウェーブレットのスケー ル, $f_{s}$ はサンプリング周波数を示す.

式（38）より，どのサンプリング周波数をとって も，アナライジングウェーブレットの中心周波数とサ ンプリング周波数の関係は相対的に等しいとしている. サンプリング周波数 $500[\mathrm{~Hz}], 1000[\mathrm{~Hz}]$ で行なった損 傷の検出結果を図 11 , 図 12 に示す.

サンプリング周波数を上げていくと本研究で提案して いる手法の適用が困難であることがわかる.これは4 自由度構造物模型が持つ4個のモ一ド以外の高い周波 数領域に存在する高次のモ一ドの影響が原因と考えら れる. すなわち，2 層目に生じる不連続性が 3 層目を 飛び越え4層目に伝播しているように見えることや， 高い周波数成分の波が遅れて現れることなどの現象が 起こっていると考えられる. 上で述べたことをサンプ ル点に着目して検証する. 図 13 に示すようにサンプ 


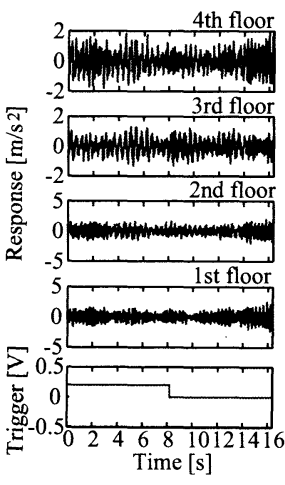

(a) Responses

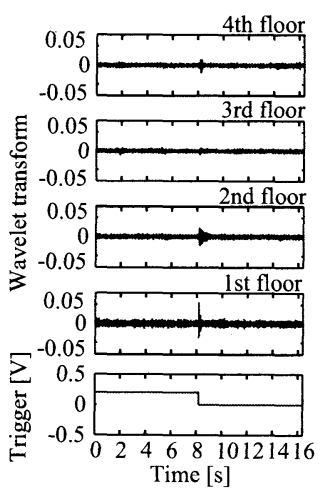

(b) Wavelet transforms

Fig.11 Consequences of the experiment (Sampling frequency $500[\mathrm{~Hz}]$ )

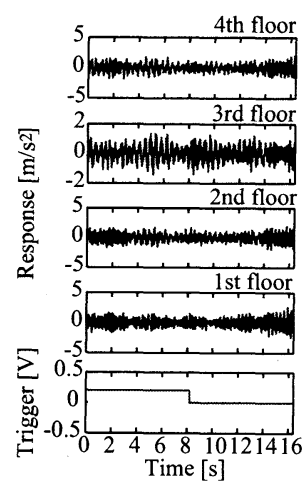

(a) Responses

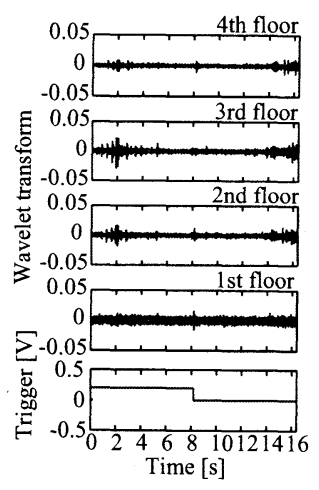

(b) Wavelet transforms
Fig.12 Consequences of the experiment (Sampling frequency $1000[\mathrm{~Hz}]$ )

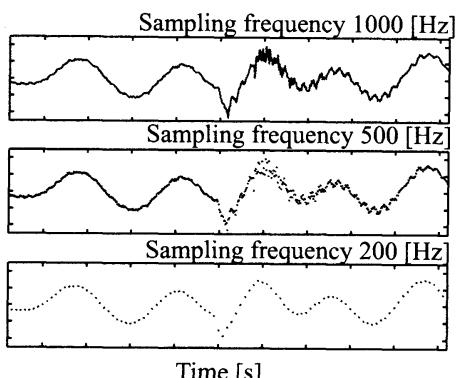

Fig.13 Difference of data points changed sampling frequency

リング周波数を大きくとると, 応答のサンプル点が多 くなるため不連続点以外の高周波な波もとらえてしま い不連続点を明確に表示できていない。逆に，サンプ
リング周波数を小さくとると，応答のサンプル点が少な いため不連続点以外の高周波な波をとらえることができ ず, 不連続点が明確に表示できている. このことより, 本研究では質点系で議論しているため, 高次のモ一ドや それに伴う高周波な波を考慮した議論は難しいが，サン プリング周波数とウェーブレットの中心周波数をうまく 選び，高次のモ一ドやそれに伴う高周波な波を考慮しな い範囲では議論することができることがわかる.

\section{6. 結 言}

本研究では, ウエーブレット変換を用いた損傷検出 手法を多自由度系へ拡張し，損傷の生じた時刻と位置を 同定する手法を確認するために，定性的な解析手法亡定 量的な解析手法を提案した.

定性的な解析手法から, 多自由度構造物において, 岡性の不連続な変化に起因する不連続性は損傷箇所に最 も近い位置でウェーブレット変換值の最も大きく，外側 の層にいくにつれて小さくなっていくという見解を得た. さらに, 定量的な解析手法から, 構造物のモデル化によ って，そのモデルの質量配分やバネ，ダッシュポットの 配置により変化する不連続波の伝播状況を可視化するこ とが可能となった. また，振動夷験による検証も行ない 本研究で提案した手法の有効性を確認した.

これらの結果より, 本研究で示した手法は今後多自由 度構造物において, 損傷位置検出に発展する際の1つの 手法として適用できると考えられる.

\section{文献}

(1) Segawa, R. et al., Experimental Study of Cumulative Damage Detection in Hysteretic Structures Using Wavelet Transform Analysis of Acceleration Response, Proceeding of the ASME PV\&P Conference, Vol.402 (2000), pp.127-135.

(2) Sone, A. et al., Health Monitoring System of Machines and Strucures by Wavelet Transform (Genration of Orthnormal Bases of Wavelets and Detection of Abnormal Signals Generated at Random Intervals), Transactions of the Japan Society of Mechanical Engineers, Series C Vol.61, No.586 (1995), pp.166-172.

(3) Al-Khalidy, A. et al., A Study of Health Monitoring Systems of Linear Structures Using Wavelet Analysis, Proceeding of the ASME PV\&P Conference, Vol.347 (1997), pp.49-58.

(4) Hou, Z. et al., Damage Detection Using Wavelet Approach and Its Applocation for On-line Health Monitoring, Proceeding of The Second World Conference on Structural Control Vol.3 (1998), pp.2351-2358.

(5) Masuda, A. et al., Wavelet-Based Health Monitoring of Randomly Excited Structures, Proceedings of the 15th ASCE Engineering Mechanics Conference, No.208 (2002), pp. 1-8. 